\title{
АРХЕОЛОГИЧЕСКИЕ ДАННЫЕ НА ТЕРРИТОРИИ БОЛГАРИИ О ВЕЛИКОМ ПЕРЕСЕЛЕНИИ НАРОДОВ
}

\author{
Б. Борисов
}

\begin{abstract}
Борисов Б. Археологически данни за Великото преселение на народите от територията на България. Анализът на сведенията в писмените извори показва, че федератски селища е имало край Кастра Мартис, Рациария, Алмус, Нове, Марцианопол, крепостта край с. Войвода, в градищата край Габрово и с. Дичин, в Ковачевско кале, Ятрус, крепостите край Хърлец, Големаново и Садовско кале, на хълмовете Царевец и Момина крепост във В. Търново. В тях са намерени известно количество накити и елементи на костюма, които напълно потвърждават сведенията в писмените извори.

Ключови думи: сармати; алани; остготи; вестготи; хуни; фибули; токи; гребени.
\end{abstract}

Борисов Б. Археологические данные на территории Болгарии о Великом переселении народов. Обзор сведений, почерпнутый из исторических источников, показывает, что федератские поселения находидись около Кастра Мартис, Рациарии, Алмуса, Нове, Марцианополя, крепости у д. Войвода, в городищах около г. Габрово и д. Дичин, Ковачевско кале, в Ятрусе, крепости у д. Хырлец, Големаново и Садовско кале, на холмах Царевец и Момина крепость в Велико Тырново. В этих поселениях открыты украшения и элементы костюма, которые вполне подтверждают сведения письменных источников.

Ключевые слова: сарматы; аланы; остготы; вестготы; гунны; фибулы; пряжки; гребни.

Borisov B. Archaeological Data about the Great Migration of Peoples from the Bulgarian Territory. The analysis of the information in the written historical sources shows that there were federative settlements near Castra Martis, Ratiaria, Almus, Novae, Marcianopolis, the fortress near Voivoda, the ruins near Gabrovo and Dichin, Kovachevsko kale, Iatrus, the fortresses near Hurlets, Golemanovo and Sadovsko kale, on the hills of Tsarevets and Momina krepost in V. Tarnovo. Certain adornments and costume elements were found in them and they absolutely confirm the written sources' data.

Keywords: Sarmathians; Alans; Ostrogoths; Visigoths; Huns; fibulas; buckles; combs.

Ранневизантийское время (IV - начало VII вв.) отмечено почти постоянными варварскими нашествиями, которые приводят к существенным переменам в этническом облике всей Европы и Северной Африки и в конечном счете - к распаду Римской империи и возникновению на ее территории ряда варварских государств. Поэтому в исторической науке принято называть этот период «Великим переселением народов». Причины этих колоссальных движений человеческих масс, породивших коренные этнические изменения и конкретные исторические события, являются предметом огромного количества научных исследований.

Эти события не обошли территорию диоцеза Фракия, куда входили и нынешние болгарские земли. В сущности, большие этнические изменения в восточной части Балканского полуострова начались намного раньше - еще в середине ІІІ в., когда имели место готские нашествия. Чуть позже, в 271-272 гг., Аврелиан вел войну против готов, карпов и роксоланов, которые отправились на юг от Дунайской границы. Большая часть побежденных карпов поселилась во Фракии. Через несколько лет, в 280 г., во Фракии поселились и 100 тысяч бастарнов ${ }^{1}$. Вероятнее всего, здесь речь идет о диоцезе, а не о провинции Фракия. С середины 280-х годов через территорию Болгарии прошли и карпы, сарматы, вандалы, астинги, певки, бургунды, тайфалы, тервинги, гревтунги, херулы, бастарны, гепиды и другие варварские племена. В исторических источниках можно найти много сведений о заселении «варварами» провинций Верхняя и Нижняя Мизия, Скифия и Фракия.

Анализ письменных и археологических сведений показывает, что варварские нашествия во время Великого переселения народов затронули нынешние болгарские земли в разной степени - намного сильнее территорию Северной Болгарии, нежели территорию Южной (Рис. 1 а). Более того, отсутствие «варварских» находок к югу от Балканского хребта дает основание некоторым болгарским ученым считать, что Великое переселение 

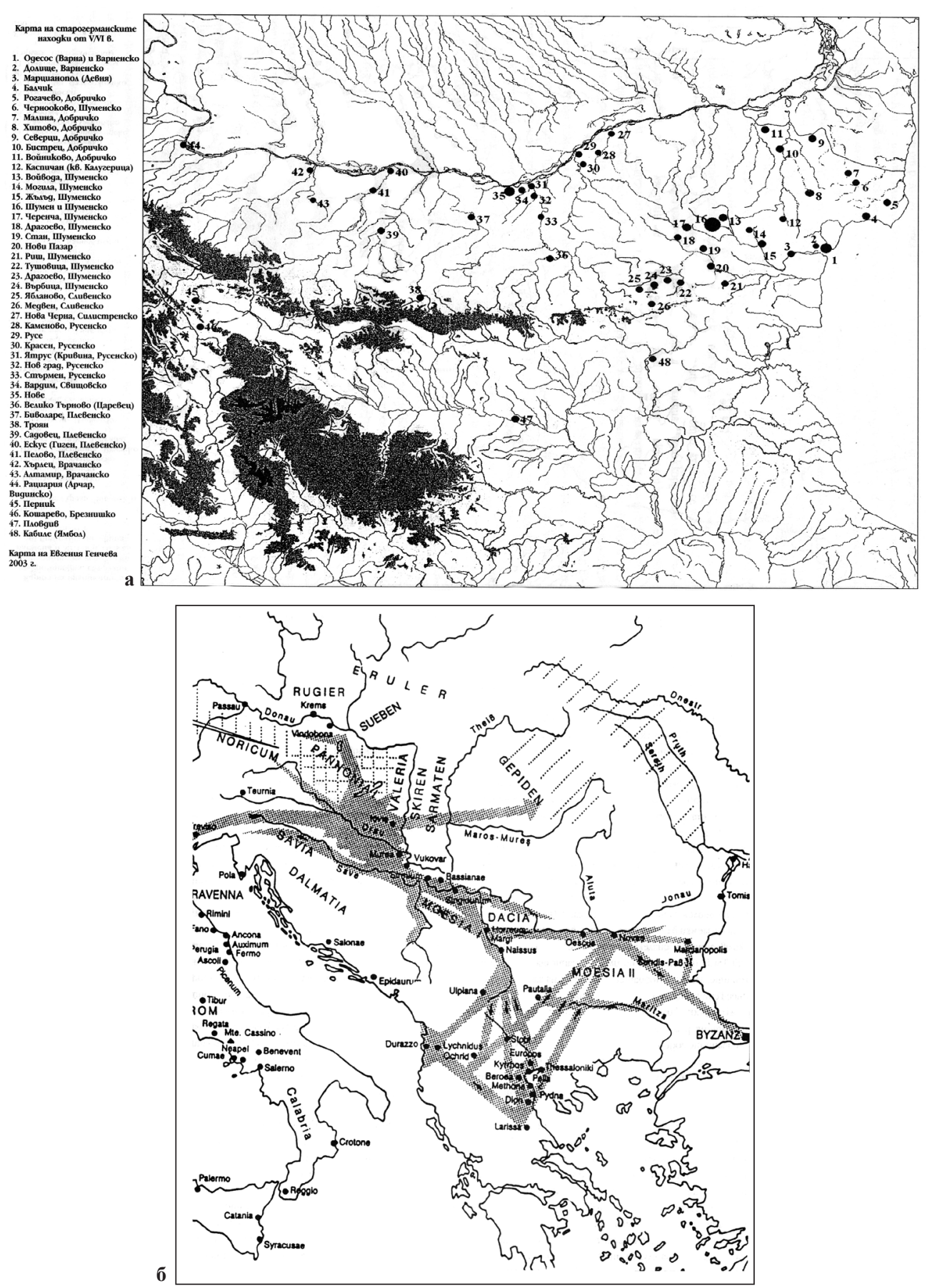

Рис. 1 а. Карта варварских находищ (Генчева Е. Готското присъствие в Нове (достижения и проблеми) // Готите и старогерманското културно-историческо присъствие по българските земи. София: Balkan Media, 2003. C. 63-68); б - Остготы V-VI вв. (Wolfram H. Die Goten auf dem Territorium des heutigen Bulgarien // Готите и старогерманското културно-историческо присъствие по българските земи. София: Balkan Media, 2003. C. 19-22) 
народов вообще не коснулось этой территории. Вот почему цель настоящего исследования - представить как можно более полную картину археологических данных, свидетельствующих о периоде Великого переселения народов и подтверждающих или дополняющих сведения из исторических источников.

В связи с обезлюдением огромных районов римские императоры начали селить там «варварское» население в качестве колонов или федератов. Они, однако, были не совсем надежным союзником власти и очень часто, особенно при задержке жалованья, поднимались на бунт против императора. По этой причине центральная власть старалась селить федератов подальше от столицы. Письменные источники также свидетельствуют о федератских поселениях, расположенных в основном на территории провинций Нижняя Мизия и Прибрежная Дакия, т.е. на территории нынешней Северной Болгарии. Федератские поселения, хотя и реже, возникали и на территории собственно Фракии. Например, в 334 г. Константин Великий поселил во Фракии, Скифии и Македонии 300 тысяч сарматовязигов ${ }^{2}$. Нет сомнения, что в данном случае речь идет о провинции, а не о диоцезе Фракия. Во второй четверти IV в. (348 г.), в результате религиозных противоречий, большая группа готов во главе со своим епископом Вульфилой получили разрешение поселиться на территории города Никополис ад Иструм (около нынешней деревни Никюп в районе г. Велико Тырново). Йордан, называя их Gothi minores, свидетельствует, что они были многочисленны и в VI в. продолжали жить в том же месте. Сведения о Gothi minores дает и Исидор Севильский, который считает, что они отказались участвовать в вестготском восстании в 378-382 гг. ${ }^{3}$. По мнению В. Велкова, часть из этих готов поселилась в крепостях на холмах Царевец и Момина крепость в г. Велико Тырново.

Вся вторая половина IV в. отмечена почти непрерывными столкновениями между Империей и вестготами, закончившиеся в 401 г., когда Аларих и подчиненные ему вестготы покинули Балканский полуостров и отправились в Италию. Множество вестготов, однако, осталось жить в качестве федератов в поселениях к югу от Дуная.

C остготами связана новая волна восточногерманских поселенцев середины V в. (Рис. 1 б). С начала Великого переселения народов и после распада остготского племенного союза они были увлечены гуннами в их поход на запад, а после смерти Атиллы в 453 г. направились на юг - в Византию, заключили с ней договор и поселились в провинциях Нижняя Мизия и Прибрежная Дакия.

Политическая борьба во время правления Льва I (457-474) стала причиной нового нарушения мира в балканских провинциях. Борьба между группировками - проготской во главе с Аспаром и происаврийской - закончилась победой второй. Аспар был убит после предательства, что привело к восстанию остготов во главе с Теодорихом Страбоном. Ранее эти остготы жили около Нове, в районе нынешнего г. Свиштов, и выполняли обязанности федератов. К восставшим остготам присоединился и другой готский вождь - Острис. Остготские повстанцы направились в Константинополь ${ }^{4}$. После этого Теодорих Страбон вступил в союз с частями армии Аспара; они захотели поселиться в провинции Фракия, но им отказали. После отказа императора остготы заняли Аркадиополь и разорили окрестности Филиппополя. Император Лев I был вынужден заключить мирный договор, согласно которому требования остготов были выполнены, а Теодорих Страбон получил право поселиться во Фракии и звание magister militum presentalis. Остготы восстановили федератские права и вернулись в свои поселения около Дуная.

В политическую борьбу за византийский престол вмешался и другой остготский вождь - Теодорих Амал, который помог Зенону получить обратно престол, за что был щедро вознагражден, получив право владеть землями вокруг Марционополя в Нижней Мизии. В 481 г., после смерти Теодориха Страбона, Теодорих Амал стал единоличным предводителем остготов, которые напали на Македонию и Фессалию. Зенон не смог остановить их и снова заключил мир, уступая им земли в провинциях Нижняя Мизия и Прибрежная Дакия. Центром вернувшихся остготов снова стал Нове к северу от Балкан. Остготская опасность для Империи миновала в 488 г., когда Теодорих Амал отправился на запад через Паннонию в Италию против Одокра. Многие остготы, однако, остались в качестве федератов в Нижней Мизии и Прибрежной Дакии и в VI в. пополнили ряды византийской армии.

Самыми поздними поселенцами на Балканском полуострове были гепиды. До смерти Атиллы они, как и остготы, находились под властью гуннов. После 453 г. часть ге- 
пидов направилась на юг. В V-VI вв. у гепидов было два центра - около Сирмиума и в так называемой Гепидии, в венгерских степях. В 567 г. гепидский союз в Паннонии был уничтожен аварами, в результате чего большая часть бежавших гепидов нашла спасение в Византии, где они получили право поселиться в качестве федератов.

Исторические источники свидетельствуют и о федератах сарматского, гуннского или лангобардского происхождения. Около середины $\mathrm{V}$ в. в устьях рек Тимок и Искар и в окрестностях Кастра Мартис поселились сарматы и гунны. Прокопий упоминает крепость $\Sigma \alpha \rho \mu \alpha \theta \omega ́ v$ и путевую станцию $\Sigma \alpha \rho \mu \alpha \theta \tau \varepsilon \varsigma^{5}$.

Во второй половине VI в. на северной границе Византии появился новый враг - авары. При Юстине не прекращались и нашествия славян, которые жили на территориях к северу от р. Дунай. В 577 г. около 100 тысяч славян перешли Дунай, достигая к югу провинций Македония и Фессалия. Во время этих нападений большая часть Фракии была разорена, а многие крепости разрушены и покинуты навсегда. Уже в следующем году возобновили свои нападения и авары. Вместе с подчиненными им славянами они взяли некоторые города, перешли через территорию Фракии, вошли в провинцию Гемимонт и взяли Анхиало. Славяно-аварские нашествия в VI в. были опустошительными и привели к гибели огромного числа поселений, крепостей, городов и к обезлюдению огромных территорий. Тем не менее славяно-аварские нашествия не прекратились, а продолжались в самом конце VI и начале VII в. при правлении императоров Тиберия Маврикия (582-602) и Фоки (602-610).

Все правление Фоки отмечено военными неудачами, в результате чего Византия снова потеряла огромные территории. При правлении Ираклия (610-641) на Империю напали одновременно персы, авары и славяне, что привело к новым потерям больших территорий. Славянские нападения участились в западной части Балканского полуострова. Была захвачена значительная часть Далмации. В 617 г. авары и славяне дошли до Константинополя 6 . В руки славян перешел и ряд крупных городов во внутренней части - Сингидунум, Наисус, Сердика и др. В 620 и 622 гг. они осаждали Салоники в третий и четвертый раз. Вместе со славянами находились авары. К концу правления Ираклия и его наследников славяне овладели почти всем Балканским полуостровом. Исторические данные говорят, что во второй половине VII в. славяне жили во всех районах Балкан - в Мизии, Фракии, Македонии, Далмации, Албании, Эпире, Фессалии, Средней Греции и Пелопоннесе 7

Обзор сведений, почерпнутых из исторических источников, показывает, что федератские поселения, вероятно, возникли около Кастра Матрис, Рациарии, Алмуса, крепости у д. Войвода в районе г. Шумена, в городище около г. Габрово и д. Дичин в районе г. Велико Тырново, Ковачевско кале в районе г. Попово, в Ятрусе, крепости у д. Хырлец в районе г. Враца. Намного более надежными можно считать данные о федератских поселениях в Големаново и Садовско кале в районе г. Плевен, на холмах Царевец и Момина крепость в Велико Тырново. В названных поселениях открыто разное количество археологических материалов - главным образом украшения и элементы костюма, которые подтверждают сведения письменных источников. Все это позволяет судить, что скудные сведения о федератских поселениях касаются в основном территории нынешней Северной Болгарии. По всей вероятности, к югу от Балкан поселилась часть тех 300 тысяч сарматов-язигов, сведения о которых содержатся и в письменных источниках.

Данные археологических исследований подтверждают сведения источников о существовании подобных федератских центров в Нове и Марцианополе, где встречаются немногочисленные находки варварского происхождения. К сожалению, археологические данные о федератских поселениях очень скудны, потому что в большинстве случаев варварские поселенцы использовали строения, которые они обнаружили. Кроме того, они пользовались ими только в определенные периоды, что еще больше затрудняет их отнесение к чисто федератским поселениям.

Намного более надежными являются археологические данные о некрополях. На северном черноморском побережье найдено несколько могильников. Первый из них - один из городских могильников Одессоса. В нем уже изучены два участка с 111 могилами, 9 из которых ориентированы на север-юг, а остальные 102 - на восток-запад (Рис. 2 а). Исследователь М. Мирчев выделяет три группы могил - к первой относится небольшое их количество, вырытых в слое чернозема (Рис. 2 б); ко второй, самой многочисленной группе, относятся могилы, вырытые в каменном пласте (Рис. 2 в). Все они ориентированы 


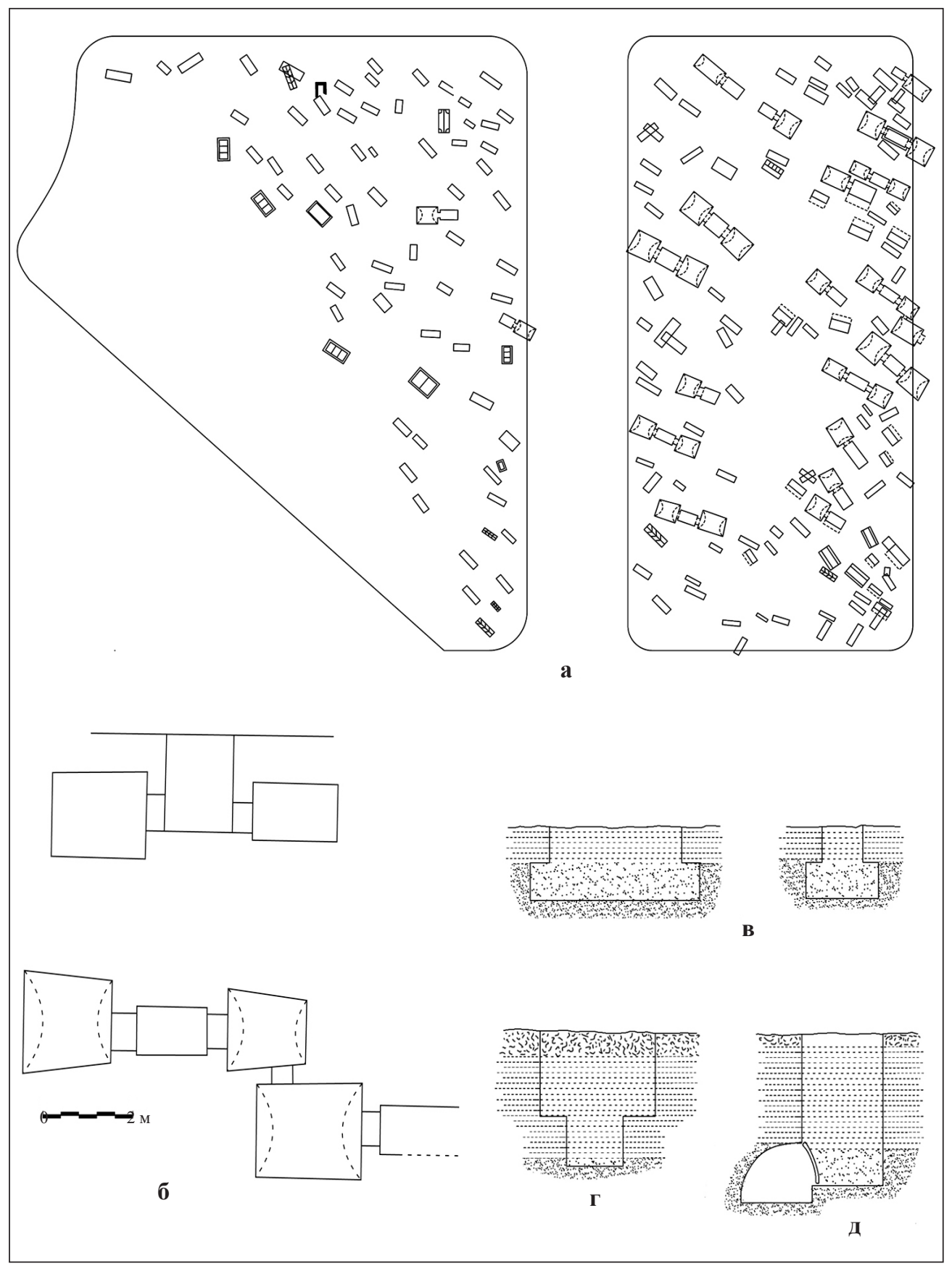

Рис. 2 а. План городского могильника Одесоса (Мирчев М. Късноримският некропол на Одесос // ИВАД. VIII. 1951. С. 92-95, обр. 139); б - План шахтовой могилы № 40 (Мирчев М. Късноримският некропол на Одесос // ИВАД. VIII. 1951. С. 92-95, обр. 140); в - Разрез вырытой в каменный пласт могилы № 9 (Мирчев М. Късноримският некропол на Одесос // ИВАД. VIII. 1951. С. 92-95, обр. 141); г - Могила с заплечиками № 14 (Мирчев М. Късноримският некропол на Одесос // ИВАД. VIII. 1951. С. 92-95, обр. 42); д - Подбойная могила № 16 
на восток-запад. Некоторые представляют могилы-корыта, а остальные - шахтовые. Ширина входных шахт - от 0,8 до 1 метра, длина - от 1,5 до 1,9 метров, а глубина достигает до 3 метров. На уровне пола с восточной, западной или с двух сторон оформлены входы с арками, которые закрываются грубой каменной плитой или тегулой. Ширина могильных камер от $1,20 \times 2$ до $2,20 \times 2,30$ м, высота от 1,20 до 1,80 м, сверху они заканчиваются полуцилиндрическим сводом. Пол собственно могильных камер всегда глубже - от 0,20 до 0,60 м, чем пол входной шахты.

К третьей группе относятся могилы с заплечиками и подбойные могилы, которые в некоторых случаях сочетаются с шахтовыми гробницами (Рис. 2 г-д). Могилы второй и третьей групп датированы концом IV, не позднее начала V в., монетами от Константина II до Валентиниана. Автор приводит в качестве параллелей могильные сооружения в Керченских некрополях, но не определяет этническую принадлежность похороненных там. Анализ могильных сооружений - могил с заплечиками, могил-ниш и шахтовых могил - показывает, что гробницы, вне всякого сомнения, связаны с сарматским погребальным обрядом ${ }^{8}$. Интерес представляет и то обстоятельство, что они обнаруживаются в городском некрополе Одессоса. Следовательно, поселившиеся в городе сарматы жили в мире с остальным городским населением.

Еще четыре некрополя находятся в местности Яйлата возле д. Камен бряг в районе г. Каварна. В первом изучены 120 могил, среди которых авторы обособляют четыре группы - к первой относятся гробницы с шахтовым преддверием и прямоугольным входом в могильную камеру. Вторая группа представлена гробницами со ступенчатым преддверием, которые в некоторых случаях закрыты сверху прямоугольной каменной плитой (Рис. 3 а-б). К третьей группе относятся гробницы-пещеры, высеченные в отвесном каменном массиве. Во всех трех видах могил (каменных склепов) камеры имеют прямоугольную или трапециевидную форму, а пол всегда глубже пола преддверия. Последнюю группу составляют корытообразные могилы, вырытые в скале. Они отличаются небольшими размерами и глубиной; в них хоронили детей. В некоторых из них оформлены углубления для каменных плит, которыми их закрывали.

Склепы являются фамильными гробницами, в некоторых из них найдены до 20-25 скелетов. Они ориентированы на запад-восток и следуют ориентации могильного сооружения. Во многих черепах есть искусственная деформация. Авторы относят некрополь к III-IV вв. и осторожно связывают его с сарматско-аланским населением, осевшим здесь во время Великого переселения народов 9 . Могилы, абсолютно идентичные могилам из местности Яйлата, найдены и в некрополе перед внешней крепостной стеной на мысе Калиакра (рис. 3 в).

Еще один могильник, который принадлежит федератскому населению, находится на мысе Чиракман, за крепостными стенами. Изучены 75 могил в овальных ямах, покрытых каменными плитами (Рис. 4). Открыта и гробница с нишей. Ориентация - запад-восток, с отклонением на северозапад, а черепа имеют искусственную деформацию. Учитывая найденные скудные находки и могильные сооружения, автор датирует некрополь IV-V вв., приводя параллели с некрополем № 1 из местности Яйлата, с Одессосом и Крымом, допуская сарматское происхождение похороненных ${ }^{10}$.

Недалеко от Черноморского побережья, около г. Провадия, открыт еще один могильник. В нем исследованы 27 вырытых в скале гробниц, которые, в зависимости от их местонахождения, можно распределить на три группы. Все без исключения гробницы разграблены еще в античности или кладоискателями (Рис. 5). Врытые в скалу могильные сооружения аналогичны по своему устройству склепам из могильника в местности Яйлата. Их датировка базируется на найденных материалах, которые относятся ко второй половине IV - первой половине V в. Устройство могильных сооружений, опять-таки, свидетельствует о сарматско-аланском происхождении населения ${ }^{11}$.

Разрушенный катакомбный некрополь открыт недалеко от д. Александрия, в районе г. Добрич. В нем изучены две катакомбы с прямоугольными входными ямами и овальными камерами, закрытыми каменными плитами (Рис. 6). Устройство катакомб, а также найденные могильный инвентарь и монеты от Аврелиана (270-275) до Валенса (364-378) дают основание авторам датировать некрополь концом III-IV вв. и вполне обоснованно связать его с аланским населением. Весьма интересно и то обстоятельство, что, кроме двух катакомб, 


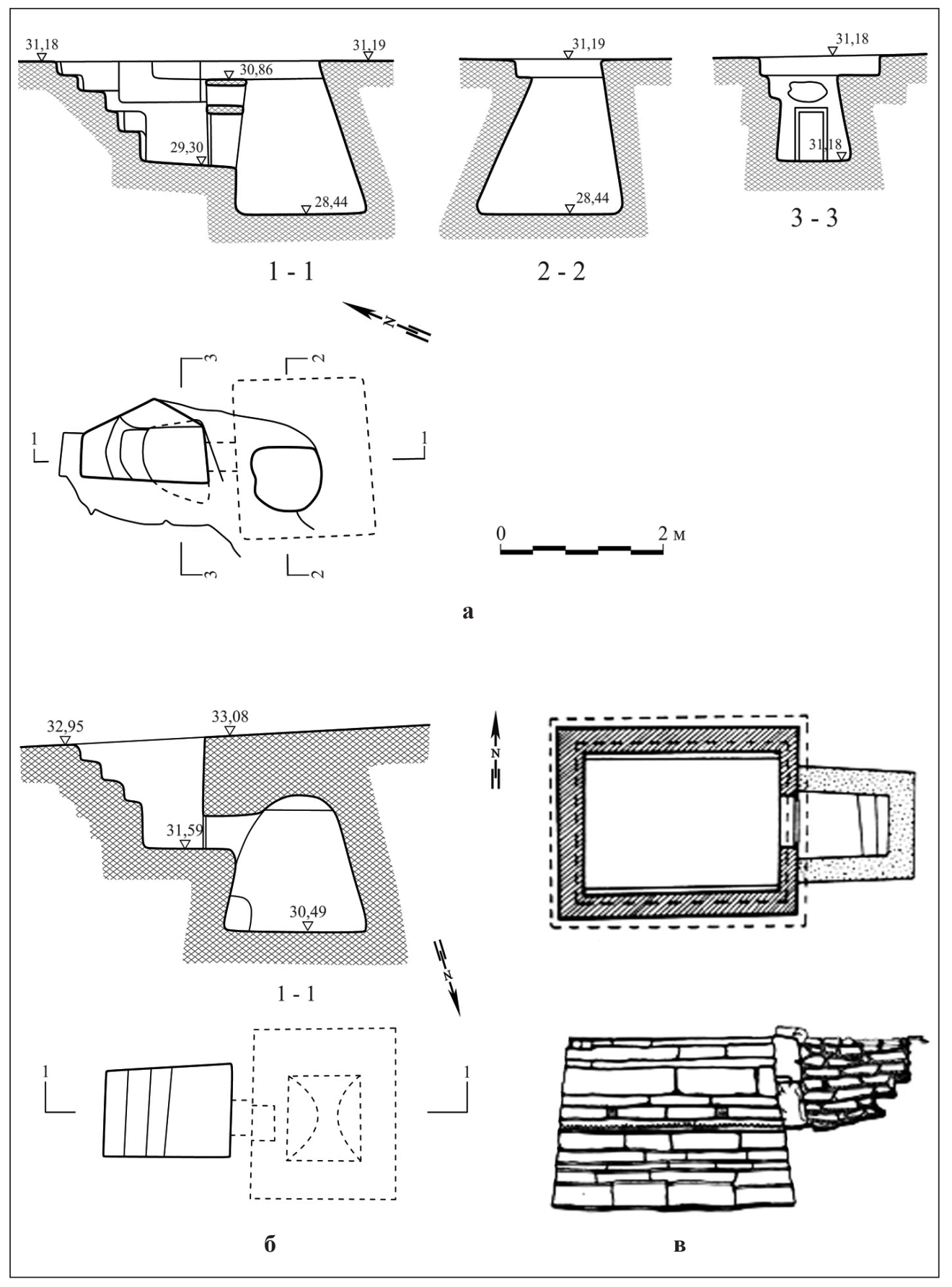

Рис. 3 а-б. План могилы со ступенчатым преддверием из могильника в местности Яйлата возле д. Камен бряг (Gatev I. Burial Rite along the Bulgarian Black Sea coast during the Late Antiquty (4th-6th Centuries) // Ниш и Византија. 2008. VI. C. 113-124. Figs. 4-5); в - План могилы из могильника на мысе Калиакра (Gatev I. Burial Rite along the Bulgarian Black Sea coast during the Late Antiquty (4th-6th Centuries) // Ниш и Византија. 2008. VI. С. 113-124. Figs. 4-5) 


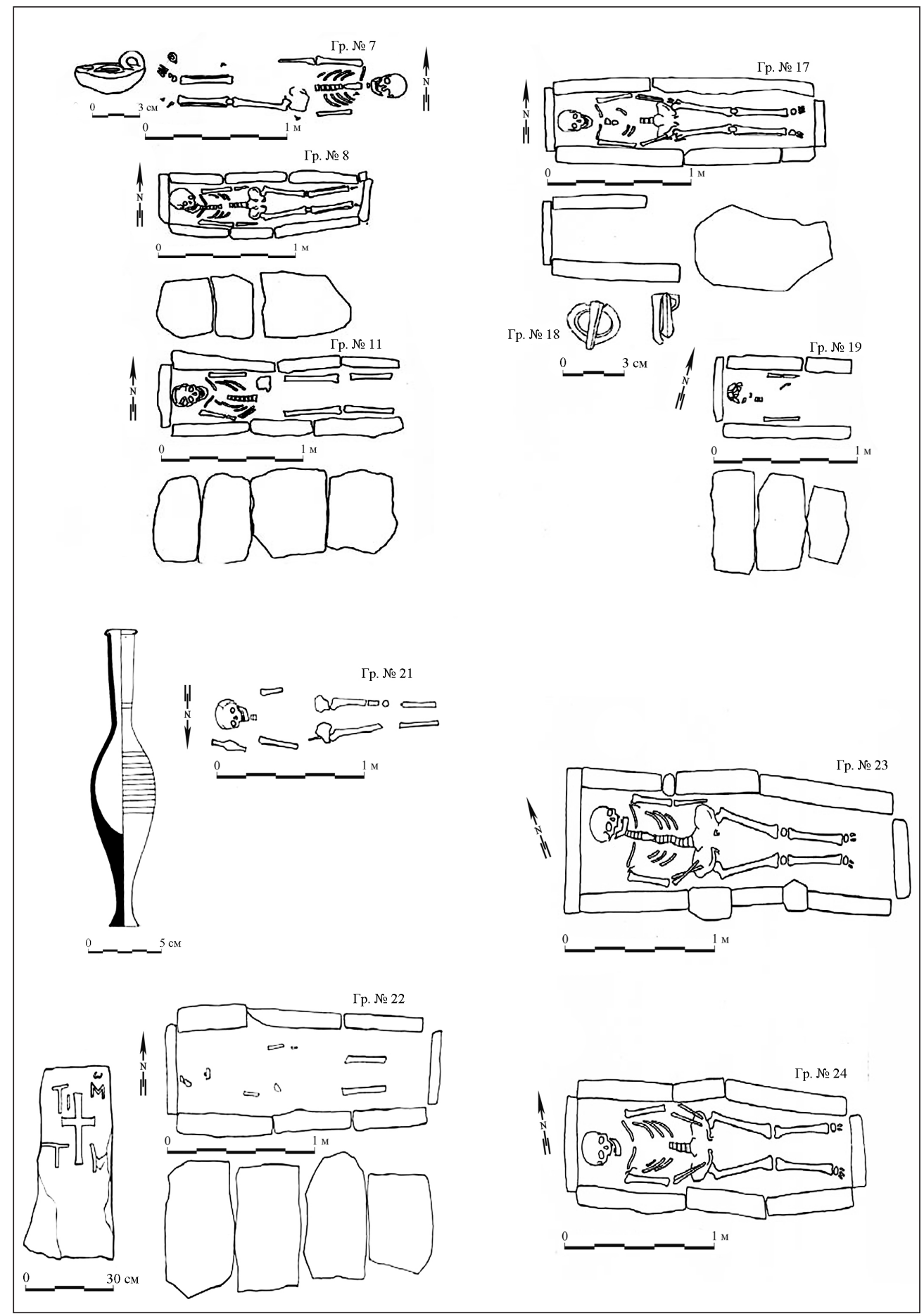

Рис. 4. Планы могилы из могильника на мысе Чиракман (Gatev I. Rescue excavations of Roman and Early Christian cemetery in Kavarna (Ancient Bizone) // Niš \& Byzantium. 2011. № IX. P. 227-236. Figs. 5-10) 


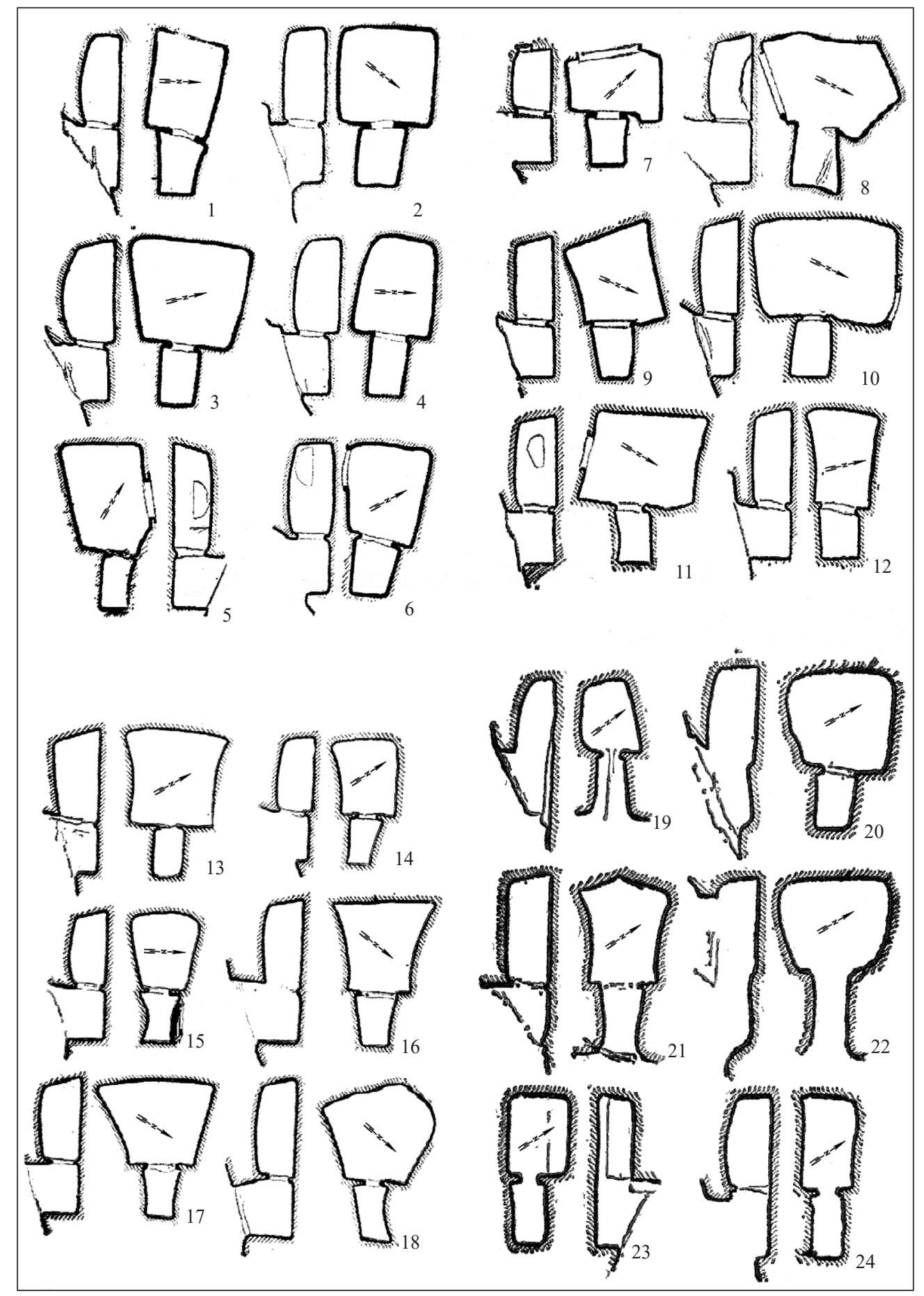

Рис. 5. Планы могил из могильника возле г. Провадия (Маргос А. Раннохристиянски старохристиянски гробници при град Провадия // ИНМВ. 1970. № VI (XXI). С. 194-196. Табл. I-II) 


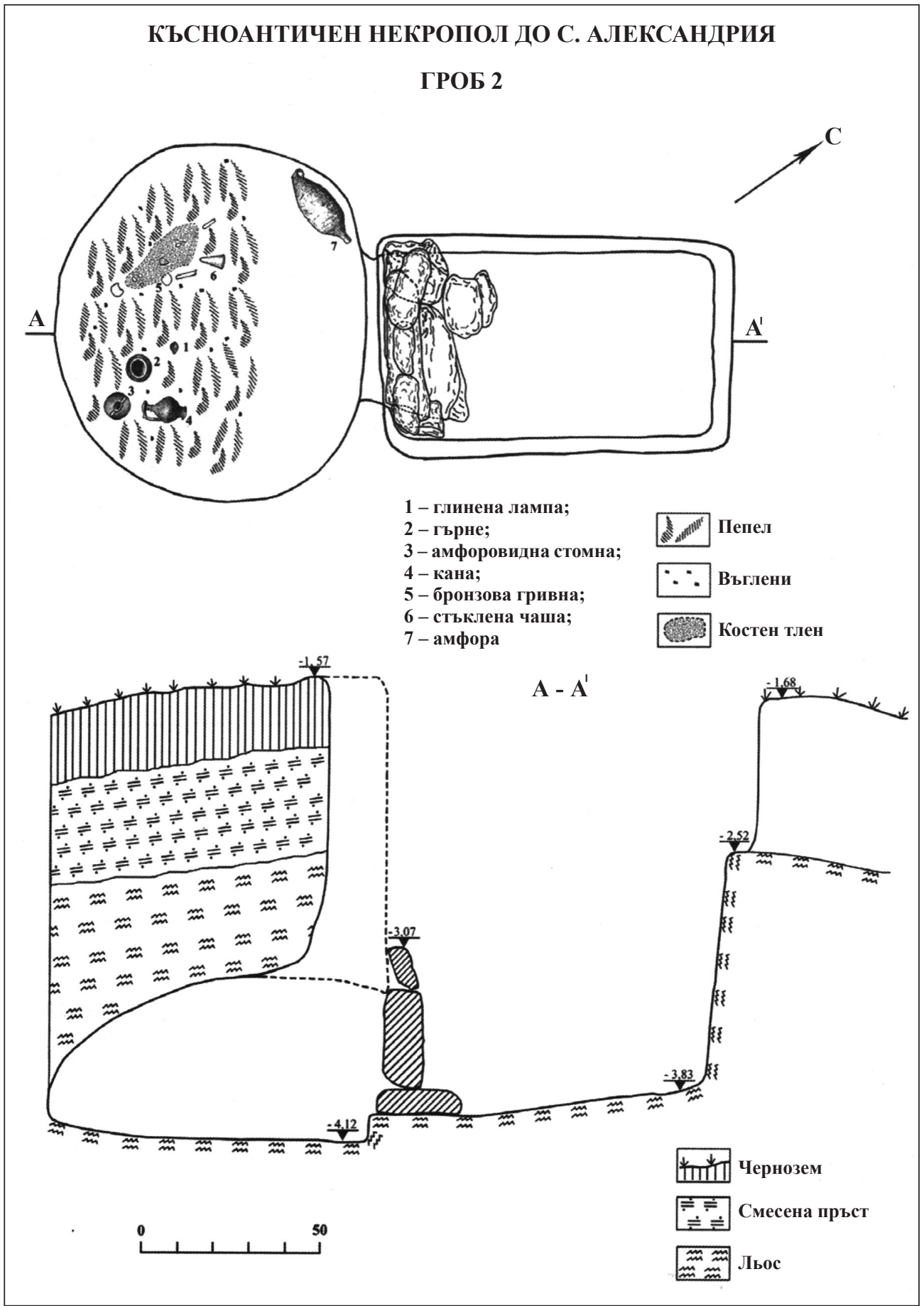

Рис. 6. План катакомбной могилы возле д. Александрия (Тотев Б. Спасителни разкопки на късноантичен некропол в м. Келисмаиловото при с. Александрия, област Добрич /Тотев Б., О. Пелевина, Д. Добрев // Архелогически открития и разкопки за 2008 г. София, 2009. С. 522-525, обр. 2) 
изучены еще две обычные ямные могилы, и это дает основание предположить, что поселившиеся здесь аланы жили в мире с местным населением, как и в Одессосе ${ }^{12}$.

Катакомбы и могилы-ниши найдены и в могильнике у д. Полковник Дяково, также в районе г. Добрич. Там изучены две катакомбные и две могилы-ниши с ориентацией запад-восток. Могилы датированы первой половиной IV в. на основе найденного инвентаря и монет. По мнению авторов, некрополь принадлежит федератскому населению, как и некрополь у д. Александрия ${ }^{13}$.

Еще один некрополь в непосредственной близости от морского берега открыт около курортного комплекса «Русалка», где изучены всего три могилы. В одной из них могильная камера - циста; две остальные врыты в скалу, а сверху закрыты камнями или каменными плитами. Ориентация -запад-восток, руки похороненного в первой могиле скрещены на животе, а в двух остальных сохранились кости только одной руки, которая тоже лежит на животе. Инвентарь найден только в могиле № 2 - бронзовая пряжка типа Сучидава, что позволило датировать некрополь второй половиной VI - началом VII в., однако, по мнению исследователя, его этническую принадлежность невозможно определить ${ }^{14}$.

Рассмотренные выше некрополи разположены недалеко от побережья Черного моря. Устройство могильных сооружений (шахтовые гробницы, могилы-ниши, ямы с заплечиками, врытые в скалу склепы), искусственная деформация черепов и ряд других особенностей погребального обряда показывают, что они принадлежат населению сарматскоаланского этнического круга. Можно предположить, что оно поселилось во время Великого переселения народов, вероятнее всего после 375 г.

Некоторые археологические данные подтверждают, что на территории нынешней Северной Болгарии были поселения не только сарматов, но и восточногерманского населения.

В Нове, пожалуй, наилучше изученном римском военном лагере среди позднеантичных городов в Болгарии, имеются единичные находки второй половины III в. «варварского» происхождения. Это фибулы с подогнутой ножкой и сосуды, украшенные блестящими полосками.

В конце IV в. окрестности Нове плотно заселены вестготами. Доказательством являются многочисленные фрагменты «федератской» керамики. Свидетельством готского присутствия считают и разрушение большого общественного здания при Валентиниане (364-375), ко времени правления которого относят и последние монеты. В то же время сожжен и хореум, где найдено большое количество «федератской» керамики.

Последний и лучше всего представленный период готского присутствия в Нове связывается с остготами Теодориха. В 476-488 гг. Нове становится центром остготов на территории нынешней Северной Болгарии. Бесспорные готские материалы найдены в некрополе, за крепостными стенами. В нем изучены свыше 100 могил, все по христианскому обычаю - на спине, с ориентацией запад-восток. Могильный инвентарь сравнительно скудный, но все же найдено немного золотых предметов, типичных для германской культуры. В некрополе обнаружены золотой браслет с утолщенными краями, две золотые фибулы, одна из них в виде ромба, другая - в форме орленка, две золотые фибулы-цикады, односторонние костяные гребни с полукруглой спинкой. Все материалы некрополя датированы приблизительно последней четвертью V в., когда готы Теодориха поселились в Нове. После ухода в Италию часть готов, во главе с Бесой, осталась в городе ${ }^{15}$.

Значительное количество находок восточногерманского происхождения открыто и в Ескусе, недалеко от д. Гиген в районе г. Плевена. Там найдены сожженные пласты, датированные монетными кладами с середины III в. В то же время были сожжены большая гражданская базилика и большое общественное здание с мозаиками. Намного ярче представлено готское присутствие во второй половине V-VI вв. В женской могиле найдены три бронзовые фибулы с позолотой, которые относят к нижнедунайскому варианту типа «Аквилея». Там же обнаружены и две серебряные гепидские фибулы с позолотой, инкрустированные альмандинами, которые относятся к первой половине VI в. В районе г. Плевена, около г. Белене (античный Димум), открыта случайно женская могила с искусственной деформацией черепа, в которой находились пара серебряных фибул, пока не имеющая аналога, и бронзовая поясная пряжка с таким же декором, как у фибул ${ }^{16}$.

В крепости Сторгозия недалеко от Плевена в IV-VI вв. поселились «варвары», которые жили вместе с уцелевшим местным населением. Красноречивым доказательством 
этому являются материалы из двух ее некрополей, севернее и западнее крепостных стен. Скелеты ориентированы на запад-восток, руки вытянуты вдоль тела, часто одна рука согнута на боку. В некрополе открыт и скелет с искусственной деформацией черепа. В другом некрополе в местности Стражата найдено большое количество фибул (луковичных и с подогнутой ножкой), поясных гарнитуров, бронзовых аппликаций, разнообразных пряжек (D-образных, прямоугольных, овальных, круглых, B-образных, типа Сучидава), поясных наконечников, а также большое количество керамики (краснолаковой и серой с блестящим декором) и стеклянных сосудов. Украшения представлены разнообразными серьгами, ожерельями, бронзовыми браслетами. Некрополь отнесен к IV-V вв. Автор выражает осторожное предположение о сарматском происхождении части погребенных ${ }^{17}$.

В районе г. Плевен есть еще несколько источников археологических материалов, которые связаны с готами или вообще с «варварским» населением (Рис. 7). Важнее всех среди них Големаново и Садовско кале, возле д. Садовец. Они расположены по берегам p. Вит. Там изучены в основном жилища и найдены разнообразные материалы, типичные

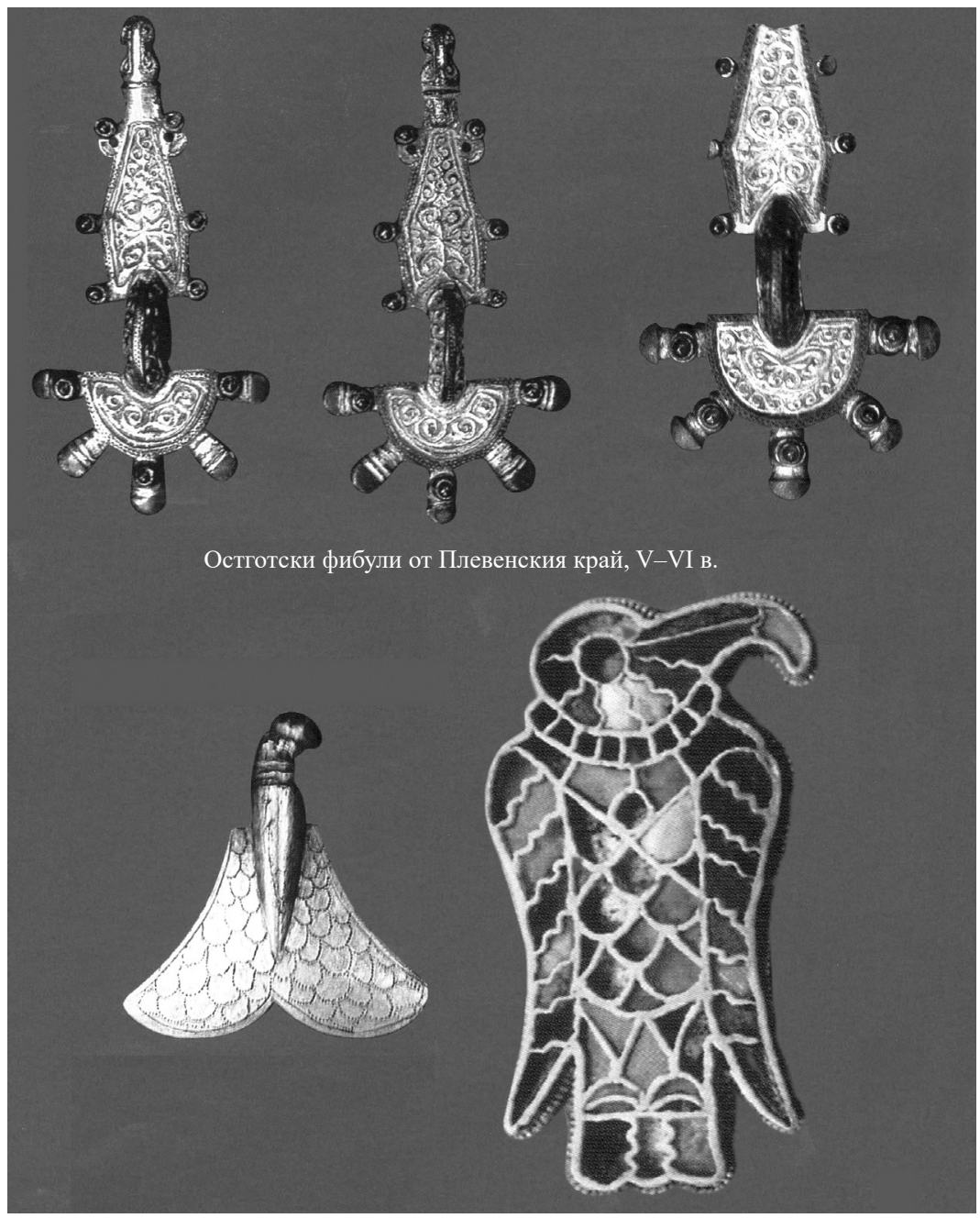

Рис. 7. Фибулы из региона г. Плевена (Ковачева Т. Готското археологическо наследие в Плевенския край // Готите и старогерманското културно-историческо присъствие по българските земи. София: Balkan Media, 2003. С. 93-94) 
для готской культуры - орудия труда, ювелирные инструменты, украшения, элементы костюма и керамики. В двух крепостях обнаружено и большое количество золотых монет, которыми платили жалованье готским федератам. Последние по времени монеты относятся к правлению Маврикия Тиберия (582-602).

К северу от двух крепостей, в районе д. Биволаре, открыты случайно две цикады, сделанные из серебра с позолотой. Они датируются второй третью V в. Еще севернее, в районе д. Комарево, найдена пара серег с полиэдром.

С готами связывают крепости Малко и Голямо кале около г. Искыр. В неизученном некрополе одной из них найдена фибула типа Гурзуф, датированная концом VI в. Фибула этого же типа найдена и в крепости у д. Хырлец, она датируется монетами Тиберия Константина (578-582). В позднеантичном поселке в местности Шишманово кале у г. Никополя найдено большое количество федератской керамики, а также пряжки типа Сучидава с крестовидной прорезью.

Большое количество «варварских» находок на территории нынешней Плевенской области, в непосредственной близости от дунайского лимеса, подтверждает сведения исторических источников о поселении федератов и лимитанеев на границе, обязанных охранять $e^{18}$. На лимесе находится также и поселение над Ятрусом, у д. Кривина в районе г. Русе, где найдены фибулы и орлиноголовые поясные пряжки, которые приписывают остготам.

Особый интерес представляет открытый недавно некрополь под аулом хана Омуртага у д. Хан Крум в районе г. Шумен. Там изучены четыре раннехристианские базилики и шесть могил с исключительно богатым могильным инвентарем - разнотипные серебряные фибулы с позолотой, позолоченная фибула-брошь, серебряные поясные пряжки с инкрустациями альмандинов, глиняные, стеклянные и золотые бусы, набор косметических инструментов, бронзовые зеркала (целое и фрагментированное), фрагментированный двусторонний костяной гребень, железный ножик и бронзовая монета Валенса (364-378 г.) (Рис. 8). Авторы датируют комплекс из четырех раннехристианских базилик и могил между концом IV и первой половиной $\mathrm{V}$ в. ${ }^{19}$. На базе аналогий в готском культурном ареале из Крыма, Среднего и Нижнего Подунавья и Западной Европы, один из двух исследователей выражает слишком смелую гипотезу о существовании Готского епископского центра в ауле у д. Хан Крум, связывая его с мизийскими готами-арианами, поселившимися в Нижней Мизии в середине IV в., не располагая при этом достаточно надежными и аргументированными доказательствами ${ }^{20}$.

Находки на территории нынешней Южной Болгарии все еще немногочисленны, но в последнее время, в результате преимущественно охранных раскопок, были открыты несколько некрополей, связанных с федератским населением. В первую очередь нужно упомянуть сарматско-аланские могильники возле д. Полски Градец, в районе комплекса «Марица-изток». Оба некрополя расположены у раннехристианской базилики. Первый - к востоку и северо-востоку от храма, второй - к западу, непосредственно перед западным фасадом базилики. К сожалению, некрополи еще не полностью изучены и пока исследованы 37 могил (Рис. 9 а).

Могильные сооружения представляют собой ямы с заплечиками, ямы с подбоем, с кирпичным покрытием, со ступенчатыми входными ямами. Открыты одна массовая могила, в которой похоронены четыре человека, и одна катакомбная могила, пока единственная на территории Южной Болгарии (Рис. 9 б). Следует отметить, что могилы в западном некрополе огорожены на поверхности участка большими камнями, в некоторых из них есть до трех рядов камней. Установлены также некоторые особенности погребального обряда - подсыпка известью, искусственная деформация черепов. Могильный инвентарь представлен серьгами - это обыкновенные кольца, бронзовые и серебряные серьги с маленьким плотным полиэдром, ожерелья из мелких или крупных стеклянных бус с бронзовыми застежками, ожерелья из позолоченных и посеребренных стеклянных бус двойной конусообразной формы, стеклянные бусы многостенной формы, бронзовые браслеты с наконечниками в виде стилизованных змеиных голов, спиральки для волос, бронзовые пряжки и глиняная посуда. Некрополи и базилики датируются второй четвертью IV - началом второй половины $\mathrm{V}$ в., что категорически подтверждается и богатым нумизматическим материалом. Анализ погребального обряда и могильного инвентаря показывает типичные 


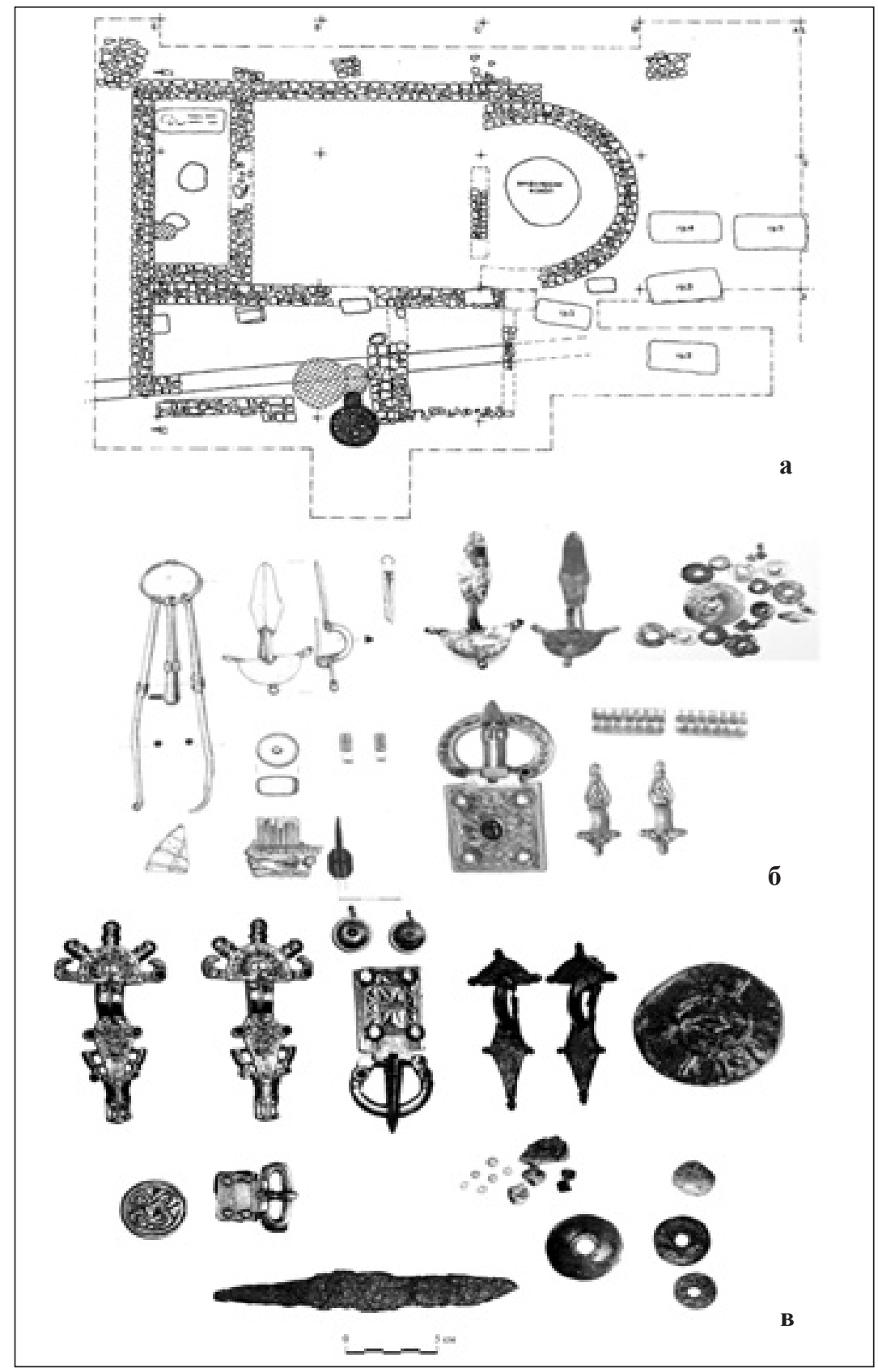

Рис. 8 a. План церквей и могильников возле д. Хан Крум (Балабанов Т. Отново за готите и епископския център от IV-V в. до с. Хан Крум, Шуменско // Великотърновският университет и българската археология. Т. 2. В. Търново: Университетско издателство „Св. св. Кирил и Методий“, 2010. С. 353); б - Инвентарь из могилы 6 (Стоева $K$. Гробна находка от времето на Великото преселение на народите от църква № 1 в аула до с. Хан Крум, Шуменско // Сб. Преслав. Т. 7. Велико Тьрново, 2013. С. 354-370, обр. 3-10); в - Инвентарь из могилы 3 (Балабанов T. Отново за готите и епископския център от IV-V в. до с. Хан Крум, Шуменско // Великотърновският университет и българската археология. Т. 2. В. Търново: Университетско издателство „Св. св. Кирил и Методий“, 2010. С. 353) 


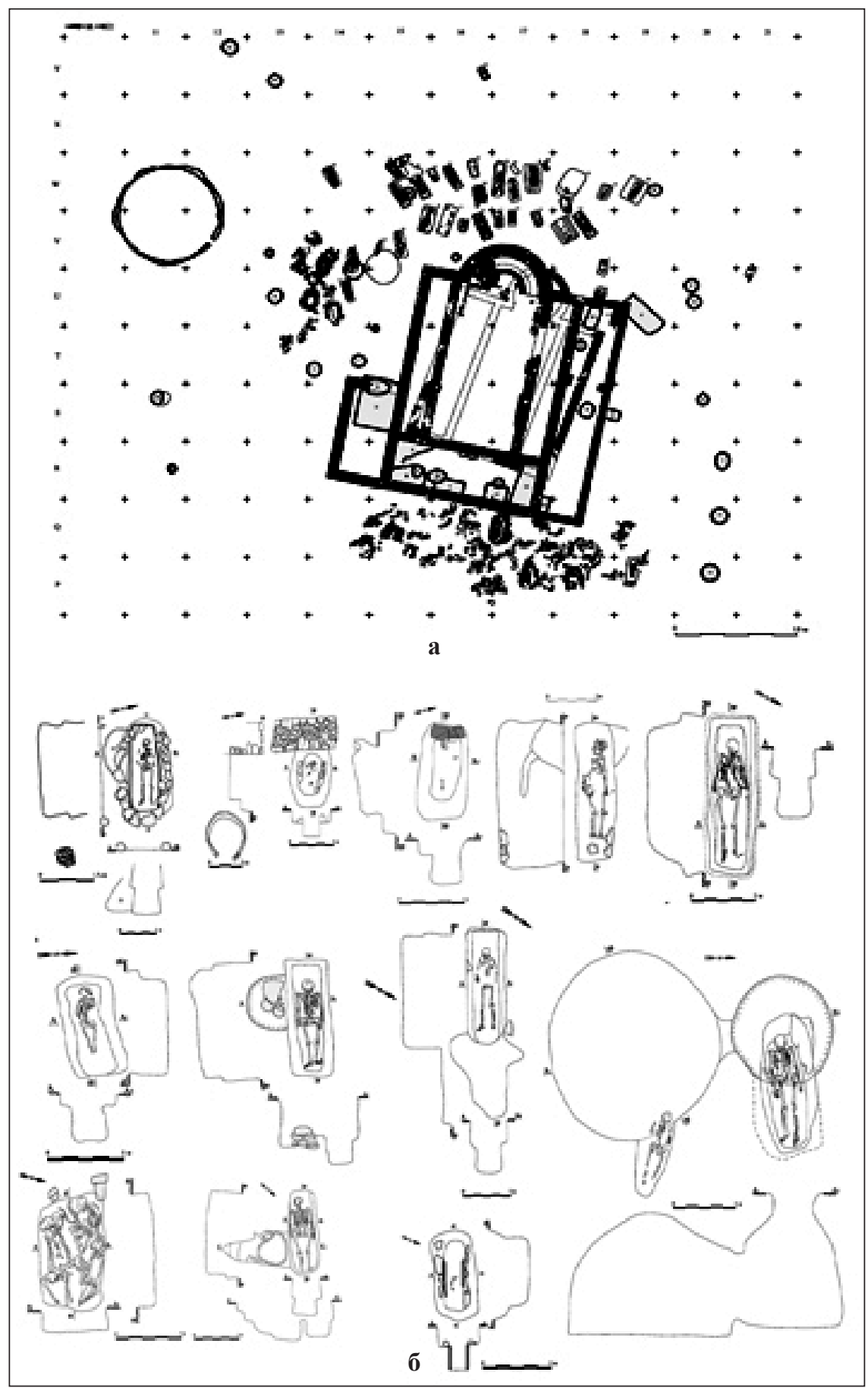

Рис. 9 а. Раннехристианские базилики и могильники возле д. Полски Градец (Борисов Б. Полски Градец. Археологически проучвания, Т. 1. В. Търново: Издателство „Фабер“, 2013, обр. 4); б - Могильные сооружения из некрополя возле д. Полски Градец (Борисов Б. Полски Градец. Археологически проучвания, Т. 1. В. Търново: Издателство „Фабер“, 2013. С. 142, обр. 43-47, 50, 54, 56, 58, 60, 64) 
характеристики населения сарматско-аланского культурного круга ${ }^{21}$. Интерес представляет и то обстоятельство, что в непосредственной близости от комплекса базилик и некрополей открыты останки синхронного поселения, которое, без сомнения, связано с могильниками. Кроме того, всего в 1,5 километрах восточнее изучена ранневизантийская крепость, функционировавшая в VI в. Существует предположение, что это крепость Сарматону $(\Sigma \alpha \rho \mu \alpha \theta \omega ́ v)$, известная Прокопию Кесарийскому 22.

Второй подобный могильник, принадлежащий сарматско-аланскому населению, находится в районе г. Твардица в насыпи кургана. В нем изучены 123 могилы, большая часть которых аналогична могилам из Полски Градец. Здесь тоже есть искусственные деформации черепов. Совпадают и могильный инвентарь, и датировка некрополя - IV-V вв..$^{23}$.

Другой некрополь на территории Южной Болгарии находится в местности Извор у д. Кошарево в районе г. Брезник. В нем исследовано 29 могил и установлено семь типов могильных сооружений. Большая часть их огорожена большими камнями или каменными плитами. Скелеты ориентированы на северо-запад и юго-восток. Зарегистрированы различные положения рук - вдоль тела, на боку или одна вдоль тела, другая - на боку. Важная особенность обряда - расположение могил рядами, а также наличие горелого дерева (углей или целых головешек) и покрытие всей могилы горящим деревом. Инвентарь найден в девяти могилах - это медные серьги с полиэдром, бронзовая В-образная пряжка с рифленной рамкой, бронзовый поясой наконечник и монеты, датированные концом IV в. В одной из могил обнаружен железный меч (Рис. 10 a). Анализ могильных сооружений, способа положения в могилу и погребальных даров дал исследователям основание высказать осторожное предположение, что некрополь в целом напоминает гепидские памятники на территории Венгрии и Румынии, но они не указывают с уверенностью этническое происхождение погребенных ${ }^{24}$.

Еще один могильник открыт во время охранных раскопок на трассе автомагистрали «Фракия». В нем есть свыше 120 могил, расположенных рядами. Результаты исследования этого большого некрополя пока не опубликованы. Погребальный обряд и найденные материалы позволяют отнести некрополь ко второй половине VI в.

На сегодня опубликована только могила № 12, в которой найден поясной гарнитур из 14 элементов. Анализируя изученные могилы, авторы подчеркивают, что расположение могил рядами напоминает захоронения, известные в Центральной и Западной Европе как Reihengräber (могилы рядами). Что касается этнической принадлежности, авторы считают, что было бы некорректным на данном этапе определить ее, но они категорически отвергают связь с готами, полагая, что некрополь принадлежит военизированному федератскому населению, которое находилось на начальном этапе христианизации ${ }^{25}$.

В отличие от двух первых сарматско-аланских некрополей, остальные два некрополя в Южной Болгарии пока не имеют точной этнической определенности.

На территории Болгарии открыто сравнительно небольшое количество археологических памятников, в основном керамика, украшения, элементы костюма, которые в общих чертах подтверждают сведения письменных источников о варварских сообществах, возникших в период Великого переселения народов. Части найденных памятников приписывают вестготское происхождение, другой - остготское, третьей - гепидское.

Вестготские памятники представлены арбалетными фибулами с подогнутой ножкой (Рис. 10 б). Они открыты около д. Соколник (три образца), д. Войниково в районе г. Добрич, в Димуме (г. Белене), в г. Балчик, в городище около г. Габрово и крепости у д. Черенча в районе г. Шумен. Этот тип имеет параллели в фибулах из Черняхово и Скалистое в Украине, из Сантана де Мурешт, Тыргшора, Индепенденцы, Будешта, Малайешта и Пятра Фрекацей в Румынии.

Второй тип представлен двупластинчатыми фабулами, в нем выделяются два подтипа - маленькие и большие (Рис. 11 а). Первый подтип представлен фибулами из Нове, Рациарии, д. Долиште в районе г. Варна, д. Войвода в районе г. Шумен и Ятруса, а второй - из Лома и Марцианополя. Этот тип фибул распространен от Крыма до Испании, где он известен как тип «Лаа ад дер Таа-Мад-Колут-Смолин». Датируются концом второго десятилетия - серединой V в. 


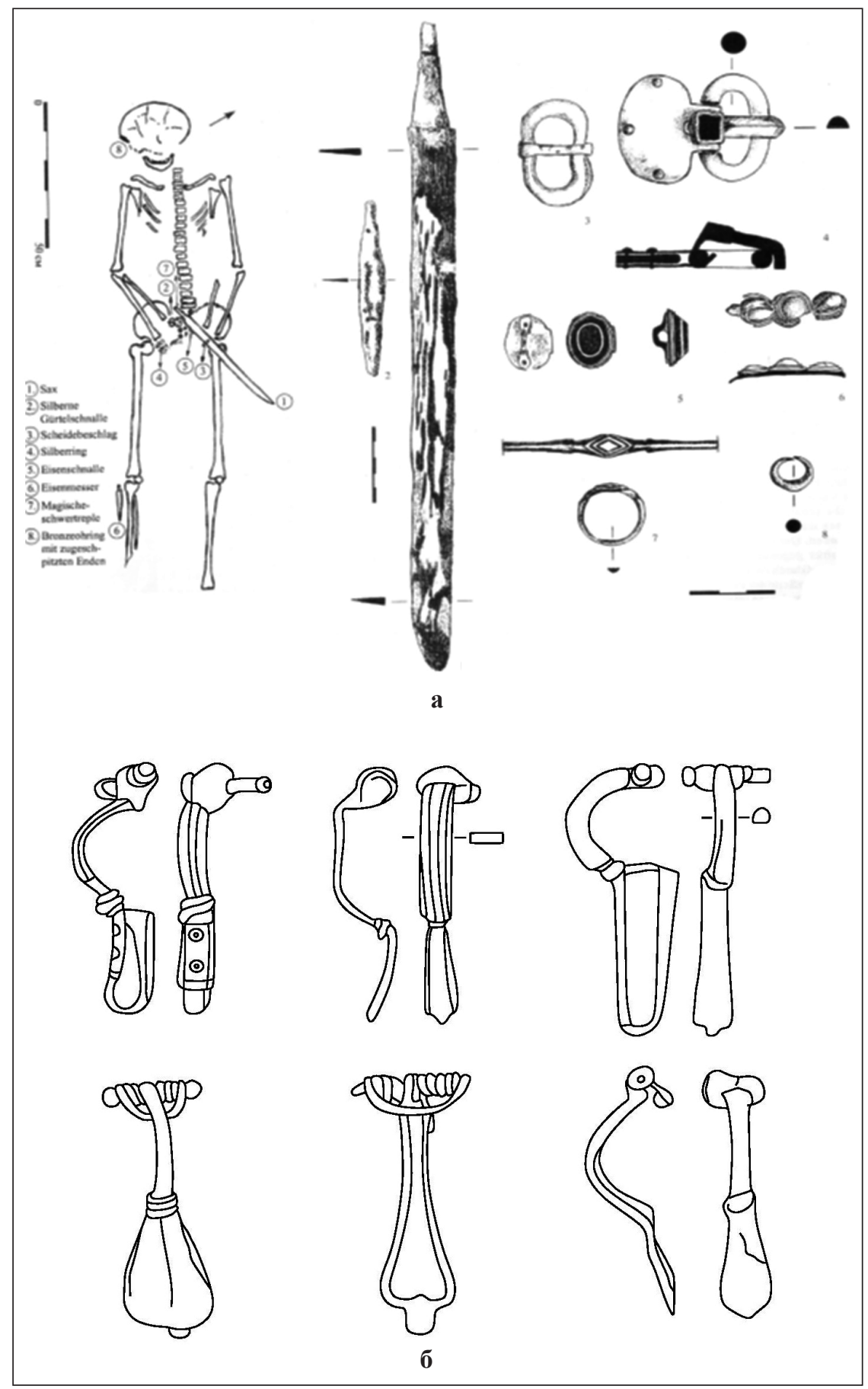

Рис. 10 a. Могила из некрополя возле д. Кошарево, Перникского региона (Даскалов $M$. Некропол от времето на готското присъствие по българските земи в м. Извор /М. Даскалов, К. Трендафилова // Готите и старогерманското културно-историческо присъствие по българските земи. София: Balkan Media, 2003. С. 97-99); б - Вестготские фибулы 


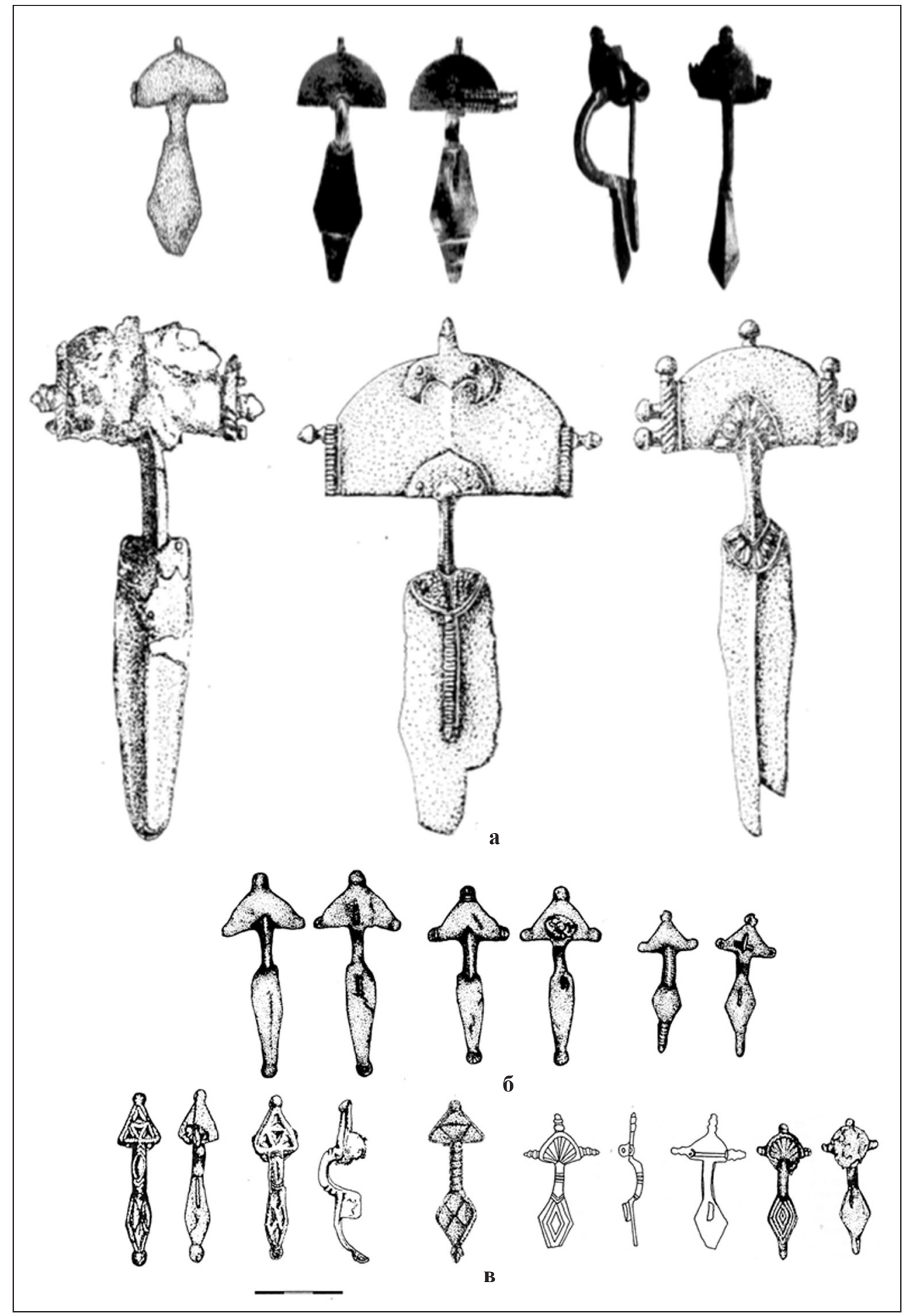

Рис. 11. Двупластинчатые фибулы 
Третий тип - «Братей» (Рис. 11 б). Фибулы также происходят из Северной Болгарии - д. Ботево в районе г. Варна, д. Северци и Рогачево в районе г. Добрич, д. Нова Черна в районе г. Силистра. Фибулы имеют параллели среди фибул из Братея, Бригецио, Смолина, Михалъца, Пятра Фрекацей и Карнунтума и датируются концом IV - серединой V в.

Вестготские пряжки представлены одним экземпляром из Ятруса, который сделан из нефрита и имеет D-образную форму рамки. Датируется от второй четверти IV в. до второй четверти $\mathrm{V}$ в.

К вестготским памятникам относятся и пять односторонних гребней с полукруглой спинкой. Они происходят из Ятруса, Нове, Ковачевско кале и Никополиса ад Иструм (два образца). Датируются IV в.

В Северной Болгарии найдено и несколько амулетов типа «Донар - Тор» из оленьих рогов. Они происходят из Нове, Ятруса, Абритуса и городища у д. Дичин в районе г. Велико Тырново.

Больше разнообразия встречается среди остготских памятников. Фибулы представлены несколькими типами. Первый - «Левице-Прша». Они происходят из д. Чернооково, Драгоево и Варбица в районе г. Шумена, Бистрец, Добричко, крепости Царевец в г. Велико Тырново и из Русе. Их параллели можно увидеть среди фибул из Скалистое в Украине, Левице и Прши в Словакии, Чонграда в Венгрии, которые датируются второй половиной V в. Второй тип представлен цикадами. Они найдены у д. Биволаре в районе г. Плевен и в Нове, датируются V в. Третий тип - «Бакудпуста-Земун», будучи обнаруженным в д. Медвен в районе г. Сливен, в Нове, д. Стан в районе г. Нови Пазар; датируются концом V в.

Следующий тип пальчатыми фибулами - «Аквилея» (Рис. 12 а). Такие найдены у д. Войниково в районе г. Добрич, Ескуса, д. Красен в районе г. Русе, в Рациарии, Одессосе, Марцианополе, Ятрусе, д. Драгоево в районе г. Шумен и др. Датируются концом V - началом VI в. Все найдены в Северной Болгарии. Две фибулы, пока без аналогов, представляют следующий тип. Они найдены в Садовско кале и вылиты из бронзы в одной и той же форме (Рис. 12 б). Датируются второй половиной V - концом VI в. или началом VII в. Последний тип фибулы - «Гурзуф» (Рис. 12 в). Они происходят из Малкото кале у д. Пелово, крепости Августа у д. Хырлец в районе г. Враца, из Шуменской крепости и д. Стан в районе г. Шумен. Этот тип имеет самые точные параллели среди памятников Крыма - из Керчи, Гурзуфа, Херсонеса - и датируется началом VI - первой половиной VII в.

Остготские пряжки относятся к двум типам. Первый представлен пряжкой, вылитой из серебра, найденной в Садовско кале, вместе с двумя уникальными по форме фибулами, и датируется, как и они, второй половиной V - концом VI в. или началом VII в.

Второй тип - это «орлиноголовые» пряжки (Рис. 13 а). Они найдены в Ятрусе, в городище у д. Риш в районе г. Шумен, в городище у д. Горски Горен Полски Трамбеш в районе г. Велико Тырново, в крепости у г. Свиштов. Имеют аналоги среду фибул того же типа из Суук-су, Керчи, Скалистое, Чифут кале и др. Орлиноголовые пряжки являются частью женского костюма и встречаются у вестготов, остготов и гепидов после середины V в.

C мужским остготским костюмом связаны пряжки типа «Калиакра». Они найдены на мысе Калиакра и у д. Живково в районе г. Шумен и датируются концом VI - серединой VII в (Рис. 13 б).

К остготским находкам относятся и литые бронзовые браслеты с утолщенными краями, которые обнаружены в Нове, Големаново, Садовско кале и Ятрусе. Такие же браслеты найдены и в Скалистое, Чифут кале, Пятра Фрекацей, Доломушпуста. За пределами Болгарии образцы встречаются в могильных комплексах и датируются весьма широкими границами - от второй половины V до первой половины VII в.

На территории Болгарии выявлены и остготские костяные гребни. Они, в отличие от вестготских, двусторонние и тоже сделаны из трех связанных друг с другом пластинок. Найдены в Никополисе ад Иструм, Марцианополе, Ятрусе, Нове, Големаново кале и в д. Ковачевец в районе г. Попово. Аналогичные гребни известны из Керчи и Пятра Фрекацей и датируются концом IV - концом VII в.

Гепидских памятников еще меньше, а во многих случаях их исключительно сложно отличить от вестготских или остготских. Все же среди находок в Болгарии можно выделить два типа гепидских фибул. Первые вылиты из серебра или бронзы и по форме и декору напоминают нижнедунайский вариант типа «Аквилея» (Рис. 13 в). Фибулы этого 


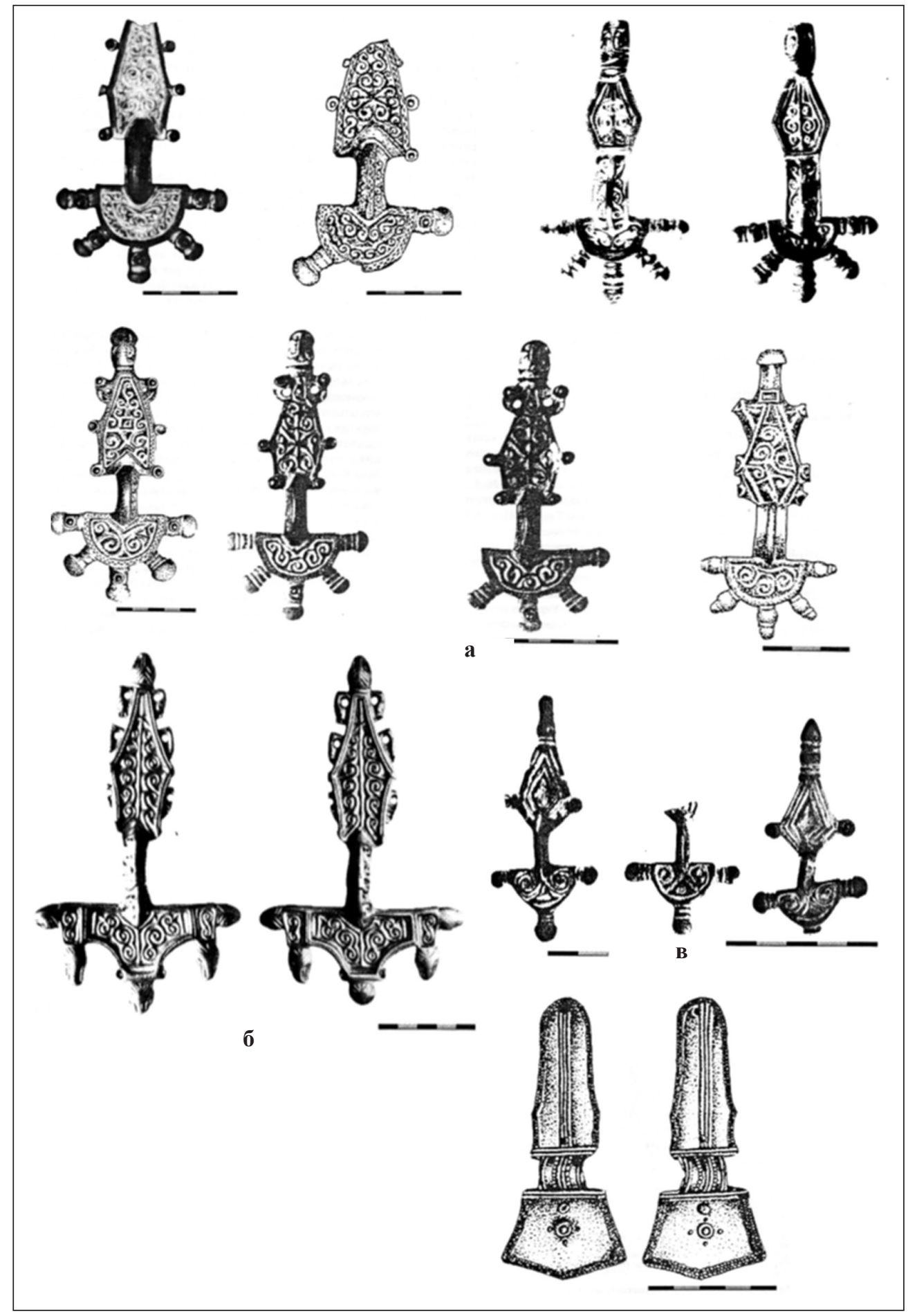

Рис. 12. Остготские фибулы 


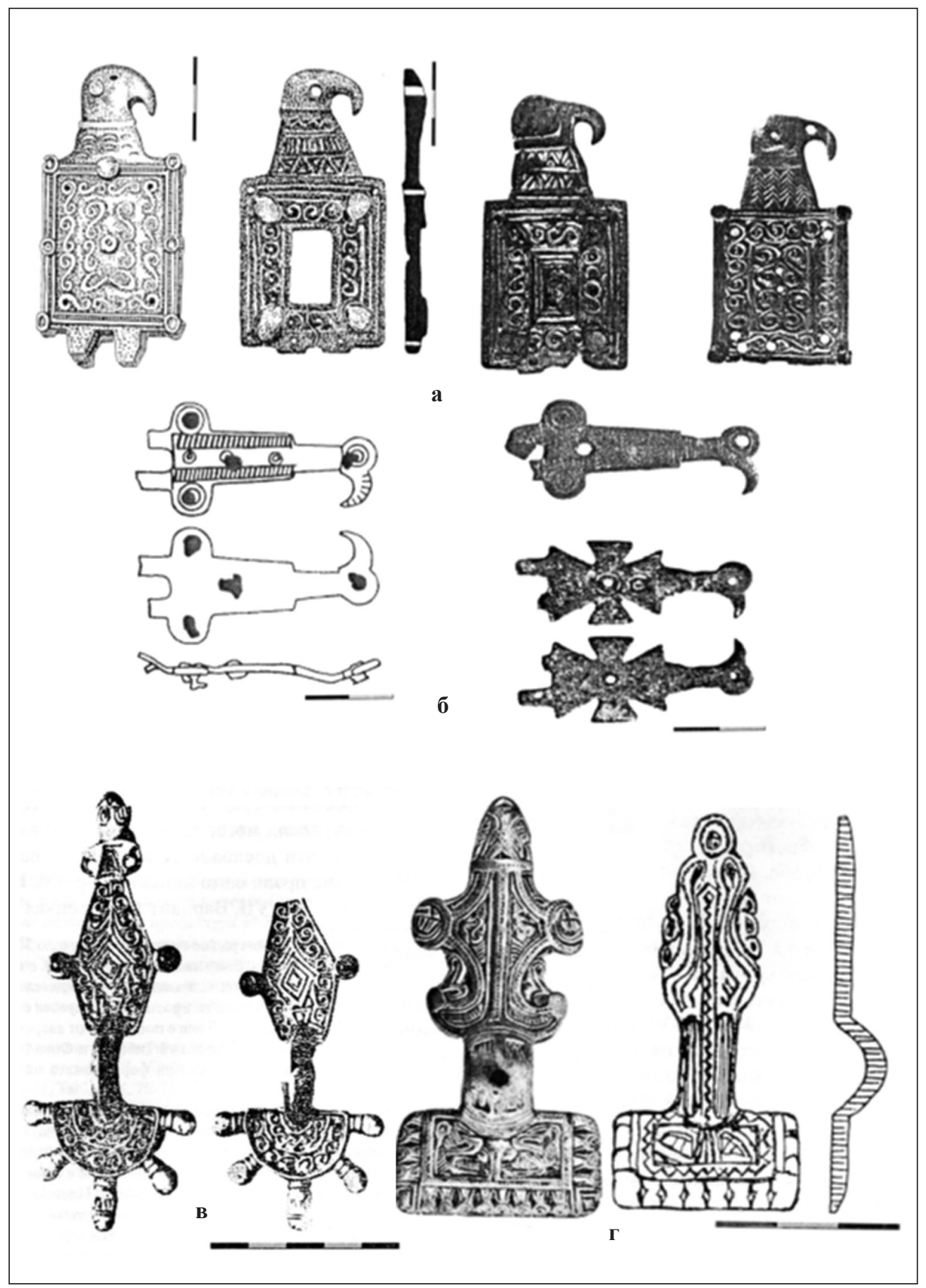

Рис. 13. Остготские орлиноголовые пряжки

a - женские; б - мужские; в - Гепидские фибулы типа „Аквилея“; г - Гепидские фибулы - „Скандинавский“ тип 


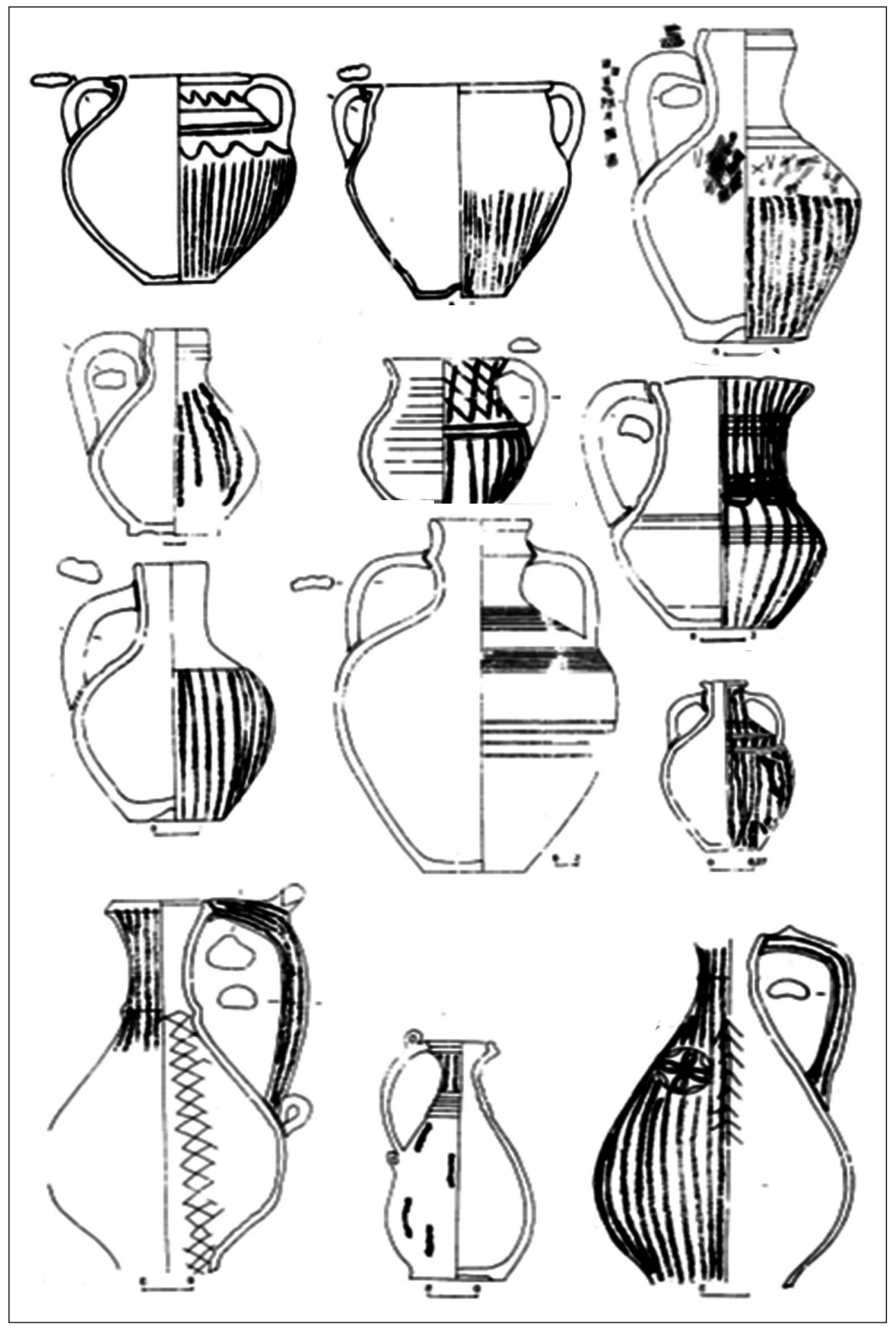

Рис. 14. „Варварская“ керамика 
типа происходят из Ескуса, Новграда, Стармена в районе г. Русе и Трояна. Самые точные параллели они имеют в Сьореге, Сентеш-Нагихеги, Сентеш-Кьокеницинге, Братей, Мореште и др. и датируются концом V - началом VII в.

Второй тип фибул - так наз. «скандинавский» (Рис. 13 г) - отличается прямоугольными пластинками с богатым декором, а ступенчатые имеют неправильную форму и заканчиваются стилизованными животными головами. Гепидские фибулы скандинавского типа происходят из крепости у д. Харлец в районе г. Враца, а также из неизвестных мест. Они имеют параллели среди однотипных фибул из Либенау, Бремен-Мандорфа, Фломборна, Гюдингена, Хале и Сьолньок-Санды. Датируются VI в. или первой половиной VII в.

Для гепидов, как и для остготов, характерны орлиноголовые пряжки, которые не отличаются от последних. В Болгарии гепидские пряжки найдены в Ятрусе, Калиакре и на Ришском перевале. В литературе их, как правило, относят к гепидам, однако этническое определение остается не до конца ясным.

Находки так называемой «серой федератской» керамики тоже сосредоточены на территории Северной Болгарии - в Абритусе, в д. Войвода в районе г. Шумен, д. Пейчиново в районе г. Русе, в Ятрусе, Сторгозии, Никополисе ад Иструм, Трансмариске, Нове, Големаново и Садовско кале в районе г. Плевен, в Кастра Мартисе, в городище у д. Якимово в районе г. Монтана, в некрополе у д. Вылчедрым, в городище у д. Дичин в районе г. Велико Тырново, в Марцианополе и ауле хана Омуртага у д. Хан Крум. В Южной Болгарии «серая федератская» керамика с декором из блестящих полос найдена только в Туиде, Августе Траяне и Дебелте.

В заключение отметим, что данные археологических исследований на территории Болгарии подтверждают сведения письменных источников. Открытые в Нове, Ятрусе, Марцианополе и Никополисе ад Иструм материалы полностью подтверждают это. Отдельные единичные находки в горных крепостях и на территории Северной Болгарии свидетельствуют о варварском присутствии в провинциях Нижняя Мизия и Прибрежная Дакия. Позже федераты смешались с остальным населением провинций и постепенно растворились в нем. Существующие пока данные о находках в Южной Болгарии весьма скудны - они известны едва с 2005 г., когда был изучен сарматско-аланский некрополь у д. Полски Градец. Нет сомнения, что будущие археологические исследования прольют новый свет на Великое переселение народов.

${ }^{1}$ Велков В. Градът в Тракия и Дакия през късната античност. София, 1959. С. 233.

${ }^{2}$ Там же. С. 234

${ }^{3}$ Там же.

${ }^{4}$ Там же. С. 43.

${ }^{5}$ Procopii Caesariensis. De Aedificiis, IV, 11 // Гръцки извори за българската история. T. II. София, 1958. C. 103-178.

${ }^{6}$ Ангелов Д. История на Византия. Ч. I (395-867). София: Наука и изкуство, 1968. С. 145-146.

7 Там же. С. 152-153.

${ }^{8}$ Мирчев М. Късноримският некропол на Одесос // Известия на Варненското археологическо дружество. 1951. Т. VIII. С. 92-95, обр. 139-142.

${ }^{9}$ Топтанов Д., Вълев П., Дерменджиев В. Ориентация на скалните гробници от некопол № 1 в археологическия комплекс «Яйла» при с. Камен бряг, Толбухинско // Интердисциплинарни изследвания. Т. XVIII. София, 1991. С. 231-234.; Gatev I. Burial Rite along the Bulgarian Black Sea coast during the Late Antiquty (4th - 6th Centuries) // Ниш и Византија. 2008. № VI. C. 113-124.

10 Гатев Й. Археологически разкопки на нос Чиракман край Каварна (античното Бизоне) през 2002 г. Проучвания на късноантичен некропол от IV-VI в. // Минало. 2004. № 2. С. 9-13; Gatev I. Rescue excavations of Roman and Early Christian cemetery in Kavarna (Ancient Bizone) // Niš \& Byzantium. 2011. № IX. P. 227-236.

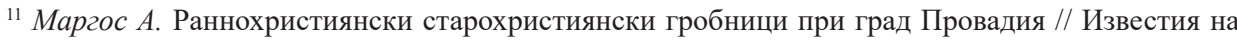
Варненския народен музей. 1970. № VI (XXI). С. 194-196, табл. I-II.

${ }_{12}$ Тотев Б., Пелевина О., Добрев Д. Спасителни разкопки на късноантичен некропол в м. Келисмаиловото при с. Александрия, област Добич // Архелогически открития и разкопки за 2008 г. София, 2009. C. $522-525$. 
${ }^{13}$ Иванов Б. Спасително археологическо проучване на късноантичен некропол при с. Полковник Дяково, община Крушари, област Добрич // Археологически открития и разкопки за 2010 г. София, 2011. С. 305-307.

${ }^{14}$ Гатев Й. Спасителни разкопки на късноантичен некропол край курорта Русалка, Каварненско // Археологически вести. 1998. № 1. С. 27-30.

${ }^{15}$ Генчева E. Готското присъствие в Нове (достижения и проблеми) // Готите и старогерманското културно-историческо присъствие по българските земи. София: Balkan Media, 2003. C. 63-67; Владкова П. Некропол край Нове от времето на Теодорих Велики // Готите. Съвременни измерения на готското културно-историческо наседство в България. София: Balkan Media, 2006. C. 56-70.

${ }^{16}$ Ковачева T. Готското археологическо наследие в Плевенския край // Готите и старогерманското културно-историческо присъствие по българските земи. София: Balkan Media, 2003. С. 93-94.

${ }_{17}$ Табакова-Цанова Г. Късноантичният некропол в местността „Стражата“ край град Плевен // Известия на Националния исторически музей. 1981. № 3. С. 102-184.

${ }^{18}$ Там же. С. $95-96$.

${ }^{19}$ Балабанов T. Отново за готите и епископския центьр от IV-V в. до с. Хан Крум, Шуменско // Великотърновският университет и българската археология. Т. 1. В. Търново: Университетско издателство „Св. св. Кирил и Методий“, 2010. С. 353; Стоева К. Гробна находка от времето на Великото преселение на народите от църква № 1 в аула до с. Хан Крум, Шуменско // Сб. Преслав. Т. 7. Велико Тьрново, 2013. С. 354-370.

${ }^{20}$ Балабанов Т. Отново за готите и епископския центьр... С. 353.

${ }^{21}$ Борисов Б. Полски Градец. Археологически проучвания, Т. 1. В. Търново: Издательство „Фабер“, 2013. С. 142.

${ }^{22}$ Там же. С. 185.

${ }^{23}$ Велков К., Кънчева-Русева T. Редовни археологически разкопки на надгробна могила в м. Лагуна, южно от гр. Твърдица // Археологически открития и разкопки през 2014 г. 2015. С. 260-261.

${ }^{24}$ Даскалов М., Трендафилова $K$. Некропол от времето на готското присъствие по българските земи в м. Извор // Готите и старогерманското културно-историческо присъствие по българските земи. София: Balkan Media, 2003. С. 97-99.

${ }^{25}$ Даскалов М., Трендафилова К. Гроб с коланна гарнитура (втора половина на VI в.) край Рупките, Чирпанско // Археология. 2005. № 1-4. С. 161-169. 